\title{
IMPROVEMENT OF KNOWLEDGE ABILITY ABOUT ECONOMIC ACTIVITIES THROUGH THE GROUP INVESTIGATION MODEL
}

\section{Peduk Rintayati, Arif Nofa Sugiyanto}

Universitas Sebelas Maret

pedukrinytayati@staff.uns.ac.id

Article History

accepted 09/07/2018

approved 01/08/2018

published 17/09/2018

\section{Keywords}

model pembelajaran

kooperatif, group

investigation, pengetahuan

kegiatan ekonomi.

\begin{abstract}
Tujuan dari penelitian ini adalah untuk meningkatkan kemampuan pengetahuan kegiatan ekonomi siswa kelas VA SDN Dukuhan Kerten no. 58 Surakarta tahun pelajaran 2017/ 2018 dengan menerapkan model pembelajaran Group Investigation (GI). Penelitian ini merupakan penelitian tindakan kelas (PTK). Penelitian dilaksanakan dalam dua siklus, dengan tiap siklus terdiri atas perencanaan, pelaksanaan, observasi, dan refleksi. Subjek penelitian adalah guru kelas dan siswa kelas VA SDN Dukuhan Kerten no. 58 Surakarta tahun pelajaran 2017/ 2018 yang berjumlah 30 siswa. Sumber data berasal dari guru dan siswa. Teknik pengumpulan data yang digunakan adalah observasi, wawancara, tes, dan dokumentasi. Validitas data menggunakan teknik triangulasi sumber data dan triangulasi metode. Teknik analisis data yang digunakan adalah model analisis interaktif yang terdiri atas reduksi data, penyajian, dan penarikan kesimpulan, serta menggunakan teknik analisis deskriptif komparatif dan teknik analisis kritis. Prosedur penelitian menggunakan model spiral yang saling berkaitan. Hasil penelitian menunjukkan bahwa model pembelajaran kooperatif tipe Group Investigation (GI) dapat meningkatkan kemampuan pengetahuan materi pokok kegiatan ekonomi siswa kelas VA SDN Dukuhan Kerten no. 58 Surakarta tahun pelajaran 2017/ 2018.
\end{abstract}

Social, Humanities, and Education Studies (SHEs): Conference Series https://jurnal.uns.ac.id/shes
p-ISSN 2620-9284

e-ISSN 2620-9292 


\section{PENDAHULUAN}

Pendidikan nasional berfungsi mengembangkan kemampuan dan membentuk watak serta peradaban bangsa yang bermartabat daam rangka mencerdaskan kehidupan bangsa, bertujuan untuk berkembangnya potensi peserta didik agar menjadi manusia yang beriman dan bertakwa kepada Tuhan Yang Maha Esa, berakhlak mulia, sehat, berilmu, cakap, kreatif, mandiri dan menjadi warga negara yang demokratis serta bertanggung jawab.

Mata pelajaran yang dipelajari di SD antara lain: (1) Pendidikan Agama, (2) Pendidikan Kewarganegaraan, (3) Bahasa Indonesia, (4) Matematika, (5) IImu Pengetahuan Alam, (6) Ilmu Pengetahuan Sosial, (7) Seni Budaya dan Keterampilan, dan (8) Pendidikan Jasmani, Olahraga dan Kesehatan. Sesuai dengan tujuan pendidikan nasional, pembelajaran IPS di SDN Dukuhan Kerten Surakarta mempunyai tujuan untuk mengembangkan potensi peserta didik agar peka terhadap masalah sosial yang terjadi di masyarakat, memiliki sikap mental positif terhadap perbaikan segala ketimpangan yang terjadi dan terampil mengatasi semua masalah yang terjadi sehari-hari baik menimpa dirinya sendiri maupun yang menimpa masyarakat.

Dewasa ini guru dituntut meningkatkan pengalaman dan pengetahuannya sehingga terampil dan profesional dalam melaksanakan fungsi sebagai guru dan sebagai pendidik. Dalam proses pembelajaran seorang guru harus berupaya menyajikan bahan ajar dengan baik sehingga informasi/bahan ajar tersebut dapat diterima atau diserap dengan baik oleh para siswa dan pada akhirnya diharapkan terjadi perubahan-perubahan perilaku, baik berupa pengetahuan (kognitif), sikap (afektif), maupun keterampilan (psikomotor).

Untuk mencapai hasil belajar yang optimal baik segi pengetahuan, sikap, maupun keterampilan, guru harus berusaha memilih dan melaksanakan teknik-teknik mengajar yang dapat merangsang kegiatan belajar siswa semaksimal mungkin. Salah satu mata pelajaran yang diajarkan pada siswa sekolah dasar adalah ilmu pengetahuan sosial (IPS) Dalam pembelajaran ilmu pengetahuan sosial di sekolah dasar siswa dituntut untuk mengenal dan memahami konsep-konsep pengetahuan yang berkaitan dengan kehidupan masyarakat dan lingkungannya. Untuk memahami konsep-konsep tersebut diperlukan metode pembelajaran yang relevan agar hasil belajar yang diperoleh siswa juga optimal. Proses pembeajaran IImu Pengetahuan Sosial di SD Negeri Dukuhan Kerten Surakarta yang dilakukan masih terpusat pada guru dan berlangsung monoton.

Keberhasilan pengajaran IPS ditentukan oleh berbagai hal, diantaranya adalah kemampuan siswa dan kemampuan guru dalam melaksanakan proses pembelajaran yang sesuai dengan tujuan pembelajaran IPS dalam kurikulum.

Profesi guru dalam dunia pendidikan memiliki peran yang sangat penting dalam mensukseskan proses pembelajaran yang dilaksanakan. Dalam melaksanakan tugasnya guru harus menentukan dan membuat perencanaan pembelajaran secara seksama untuk meningkatkan kesempatan belajar bagi siswa serta memperbaiki strategi mengajar IPS. Strategi tersebut diantaranya pemilihan metode pembelajaran yang tepat dalam proses pembelajaran. Sarana dan prasarana yang ada di lingkungan pun juga harus dioptimalkan penggunaannya agar siswa lebih mudah dalam memahami materi yang disampaikan guru.

Kebanyakan di lapangan guru lebih aktif dari pada siswa. Guru banyak mengambil inisiatif dalam menetapkan dan menetukan cara memecahkan masalah. Segala sesuatu diinfomasikan secara cermat kepada anak didiknya, sehingga anak didik tinggal menerimanya. Kegiatan tersebut dapat menimbulkan kebosanan bagi para siswa karena siswa hanya sebagai pendengar. Pembelajaran seperti ini, akan menghasilkan manusia yang konsumtif, kurang kreatif dan kurang berkemampuan untuk menghadapi tantangan hidup di masa yang akan datang. 
Berdasarkan hasil observasi yang dilakukan di SDN Dukuhan Kerten Surakarta, ternyata dalam proses pembelajaran khususnya pembelajaran IPS guru masih menggunakan metode pembelajaran ceramah, metode pembelajaran tersebut kurang efektif di dalam menyampaikan materi pembelajaran IPS yang lebih banyak siswa dituntut untuk memahami suatu konsep yang jelas. Karena metode ceramah lebih mudah digunakan untuk menguasai kelas, mudah mempersiapkan dan melaksanakannya, maka para guru seringkali menggunakan metode ini secara dominan. Namun perlu disadari bahwa dalam mengajarkan IPS dengan menggunakan metode ceramah akan dapat menimbulkan kebosanan dan menjadikan siswa pasif. Jika siswa sudah merasa bosan di dalam kelas, maka mereka cenderung akan melakukan kegiatan yang bersifat mengganggu dalam proses pembelajaran. Seperti di dalam kelas siswa akan ramai sendiri, sehingga pada saat guru menyampaikan informasi, siswa kurang memperhatikan dengan seksama. Sehingga proses pembelajaran pun menjadi kurang efisien, dan tujuan pembelajaran tidak dapat dicapai secara maksimal.

Hal ini dapat diketahui dari tes awal materi kegiatan ekonomi dengan KKM 70 diperoleh hasil yang kurang memuaskan. Dari jumlah siswa 30 siswa, hanya 16 siswa $(53,3 \%)$ yang mendapat nilai di atas KKM, sedangkan 14 siswa lainnya $(46,7 \%)$ nilainya masih di bawah KKM. Artinya ketuntasan belajar hanya 53,3\%.

Masih banyak siswa yang belum mencapai kriteria ketuntasan minimal (KKM) hal itu disebabkan banyak hal, diantaranya adalah disebabkan guru lebih banyak berfungsi sebagai instruktur yang sangat aktif dan siswa sebagai penerima pengetahuan yang pasif. Siswa yang belajar tinggal datang ke sekolah duduk mendengarkan, mencatat, dan mengulang kembali di rumah serta menghafal untuk menghadapi ulangan. Pembelajaran seperti ini membuat siswa pasif karena siswa berada pada rutinitas yang membosankan sehingga pembelajaran kurang menarik. Pada umumnya pembelajaran lebih banyak memaparkan fakta, pengetahuan, hukum, kemudian biasa dihafalkan bukan berlatih berpikir memecahkan masalah dan mengaitkannya dengan pengalaman dalam kehidupan nyata sehingga pembelajaran menjadi kurang bermakna.

Proses pembelajaran yang berlangsung selama ini pada umumnya kegiatan didominasi oleh guru dan segala inisiatif datang dari guru, sementara guru menjadikan siswa sebagai objek untuk menerima hal-hal yang dianggap penting dan menghafal materi yang disampaikan oleh guru. Situasi seperti ini, menunjukkan guru yang lebih aktif sehingga aktivitas siswa hanya terbatas pada mendengarkan, mencatat dan menjawab pertanyaan. Proses pembelajaran tersebut tidak melatih siswa untuk berpikir dan beraktivitas, bahkan siswa cenderung bosan, siswa pasif dan menambah rasa takut. Guru jarang melakukan pendekatan dan membimbing siswa pada saat pembelajaran berlangsung. Bahkan kadang-kadang dalam pembelajaran, ketika guru menerangkan dan meminta siswa untuk mengerjakan soal di depan kelas banyak siswa yang tidak mau.

Selain itu pada saat guru mengajukan pertanyaan, banyak siswa hanya diam dan guru tidak mengerti diamnya ini berarti paham atau tidak paham. Kegiatan belajar mengajar IPS akan berlangsung baik apabila guru dapat menciptakan suasana belajar yang membuat siswa menjadi bersemangat dalam menghadapi suatu persoalan sehingga mereka mampu memecahkan permasalahan, dan guru bisa mengaktifkan siswa untuk berpikir. Hal ini dilakukan agar mereka berusaha memecahkan permasalahan itu dan guru membantu mereka menemukan penyelesaian serta mengkaitkan dengan dunia nyata siswa.

Pengalaman yang diperoleh siswa makin berkesan apabila proses pembelajaran yang diperoleh merupakan hasil dari pemahaman dan penemuannya sendiri yaitu proses yang melibatkan siswa sepenuhnya untuk merumuskan suatu konsep. Untuk itu sudah menjadi tugas guru dalam mengelola proses belajar- 
mengajar adalah memilih model pembelajaran yang sesuai, agar pembelajaran lebih menarik dan bermakna. Hal ini disebabkan adanya tuntutan pada dunia pendidikan bahwa proses pembelajaran tidak lagi hanya sekedar menstransfer pengetahuan dari guru ke siswa.

Penggunaan model pembelajaran yang tepat akan memberikan dorongan pada guru dalam menyampaikan pembelajaran lebih efektif, lebih menyenangkan sehingga siswa lebih termotivasi untuk mengikuti kegiatan pembelajaran. Maka pada penelitian ini peneliti menekankan upaya untuk melihat hasil penerapan model pembelajaran yang dapat meningkatan kemampuan siswa untuk berperan di kelompoknya, menerima dan menghargai pendapat dan masukan dari anggota kelompoknya, serta hasil tes pada akhir pembelajaran.

Salah satu model pembelajaran yang dapat diterapkan adalah model pembelajaran kooperatif tipe Group Investigation (GI). Model pembelajaran kooperatif tipe Gl tidak hanya mengutamakan kerja kelompok, akan tetapi tanggung jawab individu tetap dikembangkan di dalamnya. Jadi, dalam pembelajaran kooperatif, siswa belajar bersama dalam kelompok-kelompok kecil dan saling membantu satu sama lain. Jumlah anggota dalam satu kelompok bervariasi mulai dari dua sampai dengan lima (Anita Lie, 2005: 56).

Berdasarkan uraian tersebut, maka peneliti terdorong untuk melaksanakan penelitian dengan judul "Peningkatan Kemampuan Pengetahuan Kegiatan Ekonomi Melalui Model Pembelajaran Kooperatif Tipe Group Investigation (GI)" (Penelitian Tindakan Kelas Pada Siswa Kelas V SDN Dukuhan Kerten Surakarta).

\section{METODE}

Penelitian ini adalah penelitian tindakan kelas dengan subjek penelitian yaitu siswa kelas V di salah satu SD di Kota Surakarta yang berjulah 30 siswa. Sumber data dibagi menjadi dua yaitu data primer dan sekunder dengan teknik pengumpulan data yaitu observasi, wawancara, dan tes. Wawancara dengan dua cara menurut Sugiyono (2010: 194), yaitu wawancara terstruktur dan wawancara tidak terstruktur. Data tentang nilai dan prestasi siswa diperoleh melalui tes, selanjutnya dapat dibandingkan dengan nilai dan prestasi yang dicapai kawan-kawannya atau nilai standar yang ditetapkan (Nurkancana dan Sumartana, dalam Sarwiji Suwandi, 2011: 47). Analisis data menggunakan Analisis Interaktif Mattew B. Miles dan A. Michael Huberman dalam Iskandar (2008: 222) dalam proses analisis data ada tiga komponen yang harus disadari oleh peneliti. Tiga komponen tersebut adalah 1) data reduksi, 2) penyajian data, 3) penarikan simpulan.

\section{HASIL DAN PEMBAHASAN}

Berdasarkan hasil pengamatan yang dilakukan saat pembelajaran tematik materi pokok IImu Pengetahuan Sosial tentang Kegiatan Ekonomi di kelas V diketahui bahwa guru kelas menggunakan model pembelajaran konvensional dengan metode ceramah dimana proses pembelajaran didominasi oleh guru (teacher centered). Metode ceramah ini digunakan oleh guru karena dirasa lebih mudah digunakan untuk menguasai kelas, mudah mempersiapkan maupun melaksanakannya. Pembelajaran yang seperti ini kurang efektif di dalam pembelajaran IPS. Mengajarkan IPS dengan menggunakan metode ceramah akan dapat menimbulkan kebosanan dan menjadikan siswa pasif. Jika siswa sudah merasa bosan di dalam kelas, maka mereka cenderung akan melakukan kegiatan yang bersifat mengganggu dalam proses pembelajaran. Siswa akan ramai sendiri di dalam kelas, sehingga pada saat guru menyampaikan informasi, siswa kurang memperhatikan dengan seksama. Hal ini menyebabkan proses pembelajaran pun menjadi kurang efisien, dan tujuan pembelajaran tidak dapat dicapai secara maksimal. 
Berdasarkan hasil pra tindakan yang dilakukan, didapatkan hasil yang kurang memuaskan. Dari jumlah 30 siswa hanya ada sebanyak 16 siswa atau $53.33 \%$ siswa yang mendapatkan nilai sama dengan atau di atas Kriteria Ketuntasan Minimal (KKM = 70). Data ketuntasan belajar pada kondisi awal dapat diketahui pada Tabel 4.2 di bawah ini.

Tabel 1 Ketuntasan Belajar Pra Tindakan

\begin{tabular}{cc}
\hline Keterangan & Tes Awal \\
\hline Nilai Terendah & 50 \\
Nilai Tertinggi & 80 \\
Rata-rata Nilai & 66,67 \\
Siswa Tuntas Belajar & $53,33 \%$ \\
Siswa Tidak Tuntas Belajar & $46,67 \%$ \\
\hline
\end{tabular}

Atas dasar hal tersebut, peneliti mengadakan koordinasi dengan guru kelas tentang alternatif yang dapat dilakukan untuk meningkatkan pengetahuan materi kegiatan ekonomi pada siswa kelas V SD Negeri 2 Doho Girimarto. Hasil diskusi antara peneliti dan guru kelas didapatkan suatu kesepakatan untuk menerapkan model pembelajaran kooperatif tipe Group Investigation (GI) pada kegiatan pembelajaran materi kegiatan ekonomi. Guru sebagai mempersiapkan segala perangkat yang dibutuhkan dalam proses pembelajaran. Dalam tahap perencanaan ini, guru mempersiapkan Rencana Pelaksanaan Pembelajaran (RPP) lengkap dengan soal evaluasi dan lembar diskusi, lembar observasi siswa dan guru, catatan lapangan, dan media pembelajaran.

Pada siklus yang pertama terdiri dari 2 kali pertemuan. Pada tahap implementasi tindakan, pelaksanaan pembelajaran sesuai dengan Rencana Pelaksanaan Pembelajaran (RPP) yang telah disiapkan. Pertemuan pertama, kegiatan pembelajaran dimulai dengan guru membuka pembelajaran dengan salam dan doa. Setelah memberikan apersepsi dengan pengetahuan awal siswa mengenai kegiatan ekonomi di lingkungan terdekatnya, guru kemudian menyampaikan garis besar materi, tujuan pembelajaran, prosedur penilaian dan langkah-langkah pembelajaran yang akan dipelajari.

Pada kegiatan inti, guru membagi siswa menjadi 6 kelompok heterogen berdasarkan nilai pra tindakan. Masing-masing kelompok terdiri dari 4-5 siswa. Setelah berkelompok seluruh siswa mengamati peta pikiran yang telah disiapkan oleh guru mengenai materi kegiatan ekonomi yang akan dipelajari bersama. Siswa dan guru saling bertanya jawab mengenai garis besar peta pikiran yang sedang diamati. Kemudian siswa dan guru bersama-sama merencanakan tugas yang akan dipelajari. Kegiatan pembelajaran membahas seluruh dari peta pikiran yang disajikan, antara lain jenis usaha di bidang agraris dalam arti luas, jenis usaha yang menghasilkan barang dan jasa, usaha yang dikelola perorangan, jenis usaha yang dikelola kelompok, jenisjenis kegiatan ekonomi, dan cara menghargai kegiatan usaha ekonomi. Setelah semua kelompok mendapatkan materi bagiannya, setiap kelompok segera mengientifikasi materi tersebut dengan berdiskusi. Guru berkeliling membimbing dan memantau perkembangan tiap kelompok. Setelah kegiatan diskusi selesai, masing-masing anggota kelompok membuat laporan akhrir dan mempresentasikan hasil diskusi secara bergantian di depan kelas. Guru mengkonfirmasi dan mengapresiasi hasil dari diskusi siswa.

berikut.

Data yang diperoleh dari penelitian siklus yang pertama adalah sebagai 
Tabel 2 Distribusi Frekuensi Nilai Evaluasi Individu pada Siklus I

\begin{tabular}{ccccc}
\hline No & Rentang nilai & Frekuensi & Persentase $(\%)$ & Kriteria \\
\hline 1 & $60-64$ & 3 & 10 & Tidak Tuntas \\
2 & $65-69$ & 3 & 10 & Tidak Tuntas \\
3 & $70-74$ & 8 & 26,67 & Tuntas \\
4 & $75-79$ & 7 & 23,33 & Tuntas \\
5 & $80-84$ & 7 & 23,33 & Tuntas \\
6 & $85-89$ & 1 & 3,33 & Tuntas \\
& $90-95$ & 1 & 3,33 & Tuntas \\
\hline
\end{tabular}

Berdasarkan deskripsi perolehan nilai maka histogram hasil kuis inividu pada siklus I dapat dilihat pada gambar 1 berikut:

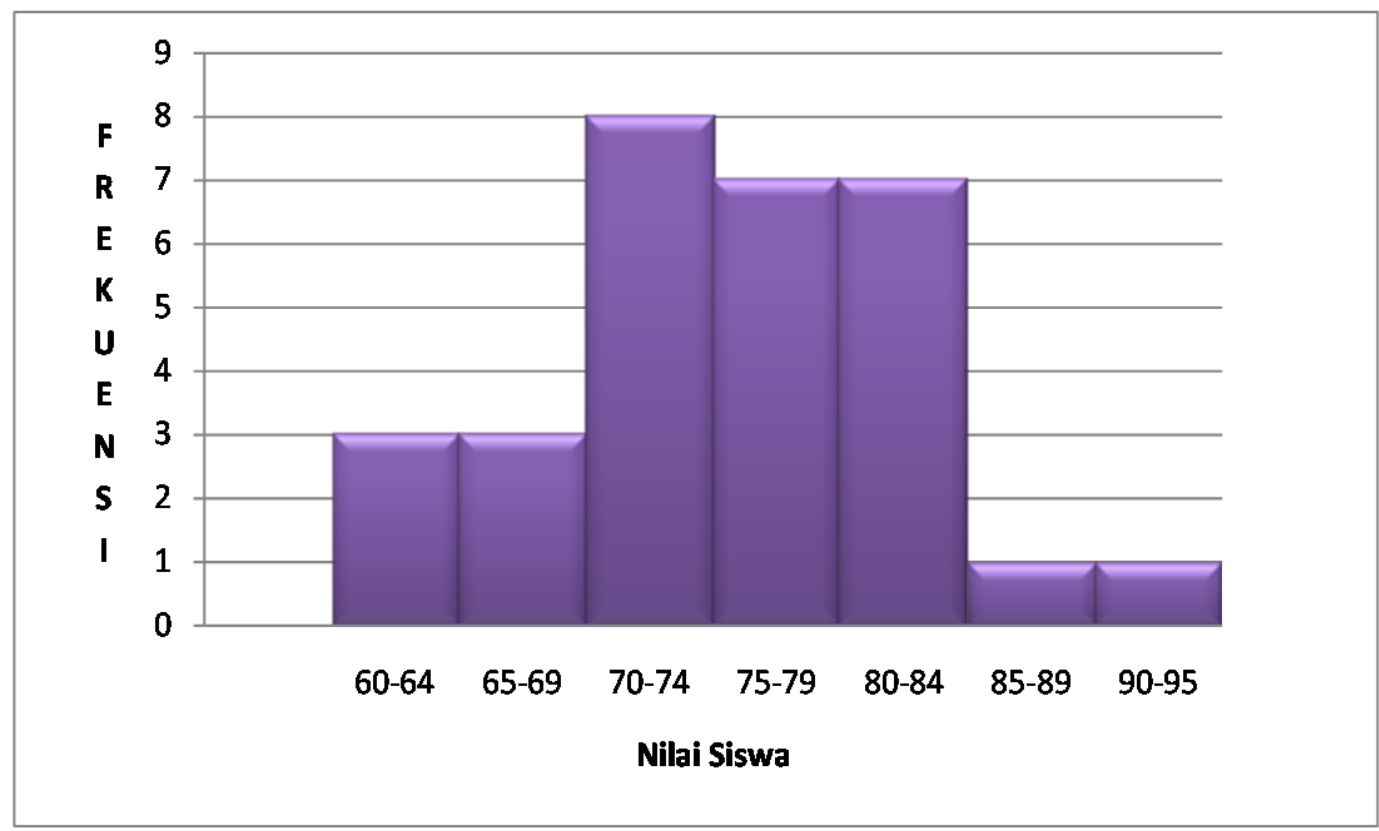

Gambar 1 Histogram Hasil Kuis Individu pada Siklus I

Siklus I yang didapat dari hasil observasi dan penilaian proses, kemudian dianalisis dan direfleksi sebagai langkah pengambilan tindakan pada siklus berikutnya. Adapun hasilnya adalah:

1) Pembelajaran belum mengarah pada student center, guru masih lebih aktif dalam pembelajaran.

2) Siswa kurang termotivasi untuk bekerja-sama dalam kelompok.

3) Penjelasan guru mengenai tugas siswa dalam pembelajaran masih kurang.

4) Pengkondisian kelas kurang, masih banyak siswa yang ramai sendiri.

5) Siswa masih banyak yang belum berani menyampaikan pendapat baik dalam proses pembelajaran.

Untuk mengatasi beberapa kekurangan pada siklus I, peneliti dan guru kolaborator kemudian mencari solusi untuk memecahkan masalah tersebut, berikut solusi yang telah didiskusikan:

1) Untuk meningkatkan keaktifan siswa, guru harus mengutamakan cara pembelajaran yang berpusat pada siswa (student center), pembelajaran harus lebih menyenangkan lagi agar siswa semangat terhadap pembelajaran yang dilaksanakan oleh peneliti. 
2) Memberikan reward pada siswa. Baik berupa pujian, penghargaan atau pun teguran bagi siswa yang aktif maupun kurang aktif dalam pembelajaran. Memberikan pengertian bahwa kerja sama dalam kelompok Hal tersebut bertujuan agar minat dan motivasi siswa dalam pembelajaran meningkat.

3) Memberikan keterangan atau penjelasan dengan lebih seksama lagi, agar siswa tidak bingung selama proses pembelajaran.

4) Pengkondisian kelas yang lebih baik, mencakup keseluruhan kelas dan siswanya.

5) Guru lebih memotivasi lagi siswanya untuk berani memengemukakan pendapat yang dimiliki pada proses pembelajaran.

6) Melakukan pertukaran kelompok secara heterogen sesuai nilai rata-rata evaluasi individu siklus I sebagai berikut:

Data yang diperoleh dari penelitian siklus yang kedua dapat dideskripsikan

Tabel 3 Distribusi Frekuensi Nilai Evaluasi Individu pada Siklus II

\begin{tabular}{ccccc}
\hline No & Rentang nilai & Frekuensi & Persentase (\%) & Kriteria \\
\hline 1 & $65-69$ & 2 & 6,67 & Tidak Tuntas \\
2 & $70-74$ & 4 & 13,33 & Tuntas \\
3 & $75-79$ & 5 & 16,67 & Tuntas \\
4 & $80-84$ & 10 & 33,33 & Tuntas \\
5 & $85-89$ & 4 & 13,33 & Tuntas \\
6 & $90-94$ & 3 & 10 & Tuntas \\
& $95-99$ & 2 & 6,67 & Tuntas \\
\hline
\end{tabular}

Berdasarkan deskripsi perolehan nilai maka histogram hasil kuis inividual pada siklus II dapat dilihat pada gambar 2:

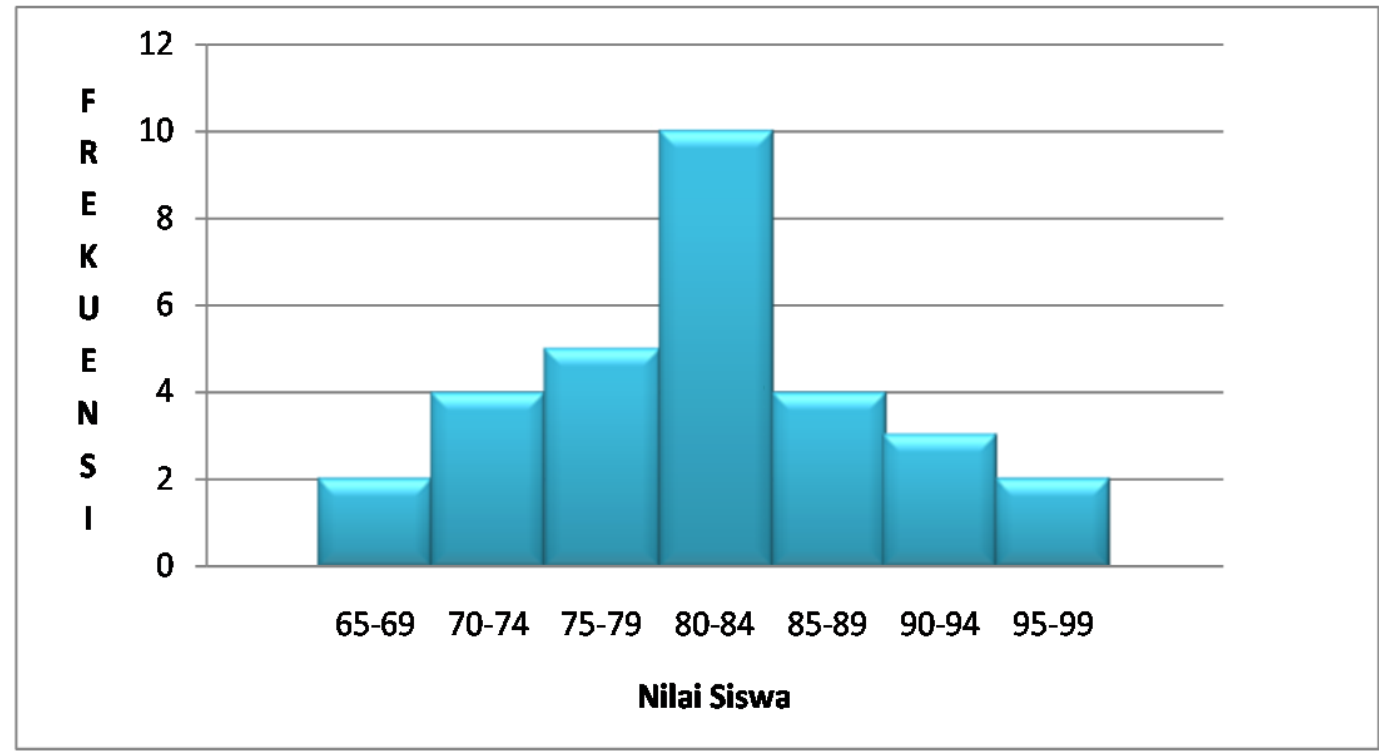

Gambar 2 Histogram Hasil Kuis Individu pada Siklus II

Berdasarkan Tabel 4.6 dan Gambar 4.4 dapat dilihat bahwa pada siklus II siswa yang memiliki ketuntasan belajar (dengan nilai 70 ke atas) sebanyak 28 siswa atau $93.33 \%$ dari jumlah 30 siswa. Dari pembahasan setiap siklus dapat 
dibuat suatu perbandingan antara siklus I dan siklus II yang dapat dilihat kenaikan pada nilai pengetahuan materi kegiatan ekonomi pada Tabel 4:

Tabel 4 Perbandingan Nilai Kemampuan Pengetahuan Kegiatan Ekonomi

$\begin{array}{llll}\text { Keterangan } & \text { Pra Tindakan Siklus I }\end{array}$

\begin{tabular}{lccc}
\hline Nilai terendah & 50 & 60 & 65 \\
Nilai tertinggi & 80 & 90 & 95 \\
Rata-rata nilai & 66,67 & 74,42 & 80,37 \\
Siswa tuntas belajar & $53,33 \%$ & $80 \%$ & $93,33 \%$ \\
\hline
\end{tabular}

Berikut untuk grafik ketuntasan siswa dalam penilaian pengetahuan kegiatan ekonomi pada siswa kelas VA SD Negeri Dukuhan Kerten Surakarta dapat di lihat pada Gambar 3:

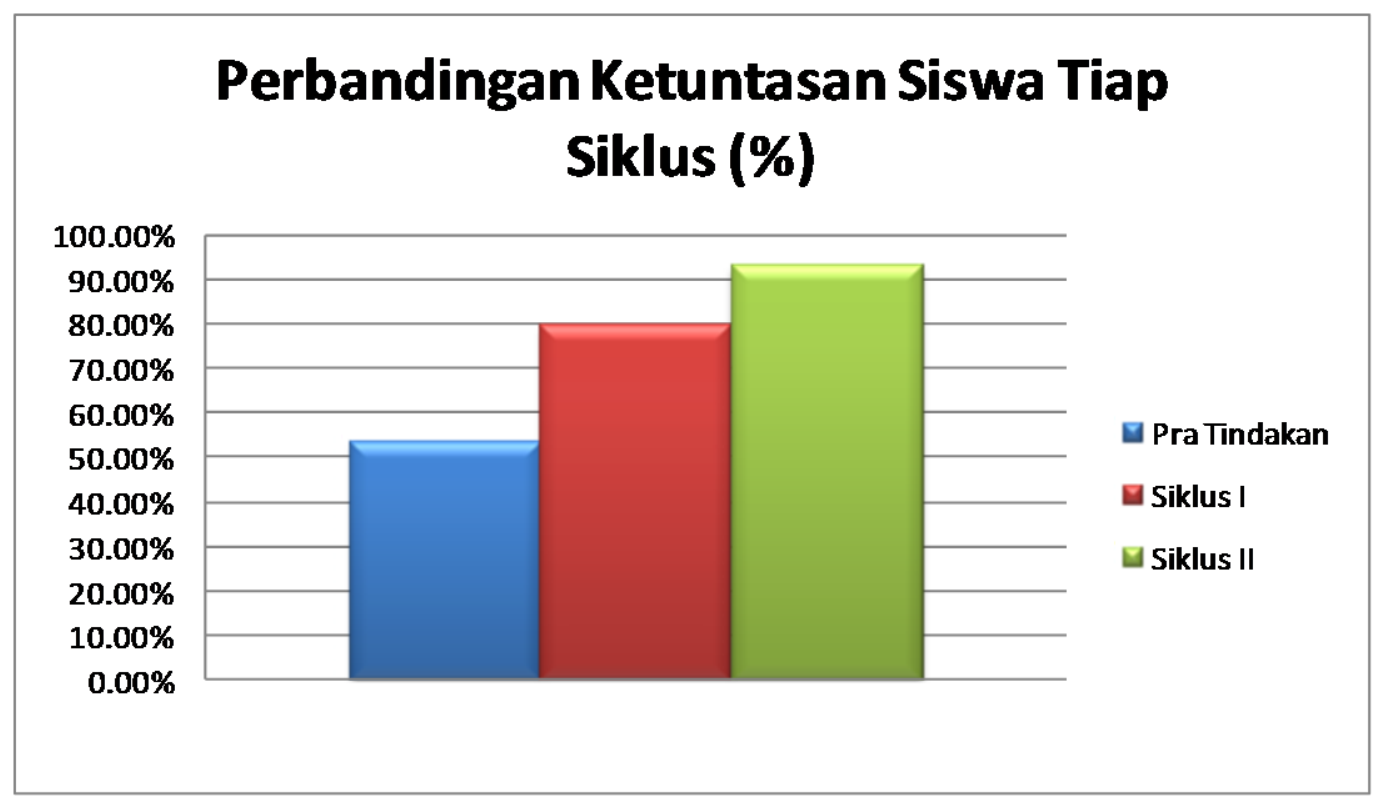

Gambar 3 Histogram Perbandingan Ketuntasan Tiap Siklus

Dari Gambar 3 dapat di jelaskan bahwa ketuntasan belanjar mengalami kenaikan dari $53,33 \%$ saat tes awal menjadi $80 \%$ pada Siklus I dan $93,33 \%$ pada Siklus II. Hasil perhitungan persentase perolehan nilai pada setiap siklus, maka dapat disimpulkan bahwa penerapan model pembelajaran kooperatif tipe Group Investigation (GI) dapat meningkatkan kemampuan siswa kelas V Sekolah Dasar dalam pengetahuan materi kegiatan ekonomi.

\section{SIMPULAN}

Hasil penelitian menunjukkan bahwa penerapan model pembelajaran kooperatif tipe Group Investigation (GI) dapat meningkatkan kemampuan siswa kelas V Sekolah Dasar dalam pengetahuan materi kegiatan ekonomi.

DAFTAR PUSTAKA

Anita Lie. 2005. Cooperative Learning: Mempraktikkan Cooperative Learning di RuangRuang Kelas. Jakarta: PT Grasindo .

Iskandar. 2008. Metodologi Penelitian Pendidikan dan Sosial (Kuantitatif dan Kualitatif). Jakarta : GP Press.

Sugiyono. 2008. Memahami Penelitian Kualitatif. Bandung : Alfabeta.

Suharsimi Arikunto. 1997. Prosedur Penelitian. Jakarta: Rineka Cipta. 